\title{
Specify Other Histologic Grade
}

National Cancer Institute

\section{Source}

National Cancer Institute. Specify Other Histologic Grade. NCI Thesaurus. Code C160791.

A request to specify the other histologic grade. 